\title{
COMENDO A UTOPIA PELAS BORDAS: AUTOBIOGRAFIA DE HILARIO HENRIQUE DICK
}

STEALTHY UTOPIA: HILÁRIO HENRIQUE DICK AUTOBIOGRAPHY

COMIENDO LA UTOPIA POR LOS BORDES: AUTOBIOGRAFÍA DE HILÁRIO HENRIQUE DICK

Hilário Henrique Dick* hiladick@gmail.com

RESUMO: Este texto apresenta a biografia de Hilário Dick, educador jesuíta e assessor da Pastoral da Juventude do Brasil. Sua vida, mesclada entre a dedicação à vida religiosa e à educação dos jovens, é apresentada a partir de um autorelato cronológico que mostra como sua trajetória foi se aproximando da educação (mestrado e doutorado) e como aconteceu a guinada e a opção preferencial pela juventude - fato que se tornou sua marca registrada e definidora de uma caminhada e realização de uma missão de vida, bem como sua produção acadêmica e bibliográfica.

Palavras-chave: Revisão de vida. Sacerdócio. Juventude.

ABSTRACT: This paper presents a Jesuit educator and Youth Ministry Brazil advisor biography, whose name is Hilário Dick. His dedication to a religious life and the youth education is presented by a chronological self-report which shows how his path encounter this field (MA and Ph.D.) which trademarked his journey, life mission, academic research and literature.

Keywords: Life review. Priesthood. Youth.

RESUMEN: Este texto presenta la biografía de Hilário Dick, educador jesuita y asesor de la Pastoral de la Juventud de Brasil. Su vida, mezclada entre la dedicación a la vida religiosa y a la educación de jóvenes, es presentada a partir de un auto-relato cronológico que enseña como su trayectoria fue aproximándose de la educación (máster y doctorado) y como ocurrió la guiñada y la opción preferencial por la juventud - hecho que se convirtió en su marca registrada y definidora de una caminada y realización de una misión de vida, bien como su producción académica y bibliográfica.

Palabras clave: Revisión de vida. Sacerdocio. Juventud. 


\begin{abstract}
Graduação em Teologia pela Pontifícia Faculdade do Colégio Máximo Cristo Rei (1970), graduação em Filosofia pela Universidade do Vale do Rio dos Sinos (1962), graduação em Letras pela Universidade do Vale do Rio dos Sinos (1965), mestrado em Letras (Ciência da Literatura) pela Universidade Federal do Rio de Janeiro (1973) e doutorado em Letras (Ciência da Literatura) pela Universidade Federal do Rio de Janeiro (1976). Atualmente é professor/pesquisador da Universidade do Vale do Rio dos Sinos. Tem experiência na área de Teologia, com ênfase em Pastoral de Juventude, atuando principalmente nos seguintes temas: juventude, educação e formação de educadores.
\end{abstract}

${ }^{1}$ Livros até a década de 1980 - O primeiro espaço foi o da literatura, não só em artigos. Também em livros: Introdução à Literatura Brasileira, São Leopoldo, 1968; Cosmovisão do Romance Nordestino Moderno, Livraria Sulina: Porto Alegre, 1970. Contudo, já em 1977 fui entrando no mundo da juventude: primeiramente para os jovens e, depois sobre os jovens: Na busca de ser - a angústia de não ser, Petrópolis: Vozes, 1977; Deus é devagar, São Paulo: Paulinas, 1978; Creio na liberdade, São Paulo: Paulinas, 1979; Quando não adianta fugir, Petrópolis: Vozes, 1980; Pastoral da Juventude no Rio Grande do Sul (coautoria), Petrópolis: Vozes, 1980; Pastoral da Juventude e Meio Social (coautoria), São Paulo: Paulinas, 1982; Pastoral da Juventude no Brasil (coautoria), São Paulo: AEC/Loyola, 1983. A década de 1990 foi, toda ela, sobre e para a juventude, destacando-se a preocupação com a história da juventude e a pedagogia no trabalho com os jovens: Aprendendo a ser novo - 15 reuniões com jovens, Vozes, 1995; Los estudiantes siendo Iglesia en América Latina: la historia de la JEC, SLA MIEC-JECI, Quito, 1994; Ojovem na Bíblia - 20 roteiros de trabalho, (coautoria) Vozes, 1995; Quem revê vê melhor - iniciação à Revisão de Vida, (coautoria), Porto Alegre: Evangraf, 1995; Juventude faz História - Pastoral da Juventude no Rio Grande do Sul 1983-1993, Porto Alegre: Evangraf, 1995; Cultivando a Mística - 32 roteiros de oração para jovens (Org.), Porto Alegre: Evangraf, 1998; $\mathrm{O} \mathrm{Ca}$ minho se faz - História da Pastoral da Juventude no Brasil, Porto Alegre: Evangraf, 1999; Jesus Cristo e os Jovens. In: Jesus de Nazaré - profeta da Liberdade e da Esperança. São Leopoldo: Unisinos, 1999, p. 331348; Gritos silenciados, mas evidentes - os jovens construindo juventude na história. São Paulo: Loyola, 2003; Cartas a Neotéfilo, São Paulo: Loyola, 2003.

Depois disso, entrei mais no caminho da pesquisa sobre jovens, introduzindo o Curso de Pós-Graduação sobre Juventude na UNISINOS e fazendo surgir, na Universidade, o Observatório Juvenil do Vale. Publicações: $O$ imaginário religioso do estudante da UNISINOS, Cadernos do IHU, ano 1, n. 1, 2002; Às margens juvenis de São Leopoldo,

\section{CONSIDERAÇÕES INICIAIS}

Nasci em 12 de maio de 1937, em Linha João Alves Santa Cruz do Sul (RS), filho de João Dick e Josefa Paulina Rabuske Dick. Estudei o $1 .^{\circ}$ e $2 .^{\circ}$ graus no Colégio Santo Inácio, em Salvador do Sul (RS); completei o bacharelado em Filosofia pela Faculdade de Filosofia, Ciências e Letras, de São Leopoldo (22.1.1963, reg. 202 folhas 101, livro 1); fiz licenciado em Português pela Faculdade de Filosofia, Ciências e Letras de São Leopoldo (20.1.2.1965, reg. 502 folhas 261, livro 1) e licenciado em Teologia pela Faculdade de Teologia Cristo Rei, de São Leopoldo (1969). Depois me tornei Mestre em Literatura Brasileira pela Universidade Federal do Rio de Janeiro (27.1.1976, reg. 1985 folhas 20 do livro n. 2 competente da Divisão de Diplomas) e Doutor em Letras pela Universidade Federal do Rio de Janeiro (13.7.1976, reg. 2247 folha $37 v$ livro n. 2 competente da Divisão de Diplomas).

Como principais atividades acadêmico-profissionais, religiosas e pastorais, destaco:

- Professor de Literatura na UNISINOS e no Colégio Anchieta (Porto Alegre);

- Assessor do Setor Juventude da CNBB de 1981 a 1983;

- Responsável do "Centro Religioso" da UNISINOS, em São Leopoldo, de 1976 a 1978; diretor dos "Órgãos Suplementares" da UNISINOS de 1977 a 1978; chefe da Divisão de Ação Pastoral da Universidade Católica de Pernambuco de 1984 a 1989;

- Assessor do MIEC-JECI (Movimento Internacional dos Estudantes Católicos e da Juventude Estudantil Católica Internacional.);

- Coordenador do Curso de Pós-Graduação: Especialização em Juventude, na UNISINOS, de 1999 até 2005. O Curso foi transferido para Goiânia-GO e, depois, para Belo Horizonte - MG;

- Coordenador e membro da Equipe Executiva do IPJ de Porto Alegre (1990 a 2001);

- Pesquisador do "Observatório Juvenil do Vale", na UNISINOS, a partir de 2004 até o momento presente, 2016;

- Professor de história da juventude no Curso de Pós-Graduação: Especialização em Juventude na UNISINOS e na Casa da Juventude, em Goiânia (2005 a 2011).

Desde 1965 publicava artigos literários, históricos e pastorais. Apresento somente livretos e livros ${ }^{1}$. Se fosse destacar, citaria: Na busca de ser - a angústia de não ser (pela sua aceitação); Deus é devagar (por sua beleza juvenil); Juventude faz História - Pastoral da Juventude no Rio Grande do Sul 1983 - 1993 (por sua necessidade); O Caminho se faz - História da Pastoral da Juventude no Brasil (por sua importância); Gritos silenciados, mas 
Cadernos do IHU, n. 11, 2005; Acompanhamento - Mística do acólito da juventude. São Paulo: CCJ, 2008; Discursos à beira dos Sinos - a emergência de novos valores na juventude: o caso de São Leopoldo. Cadernos do IHU, ano 4, n. 18, 2006; Para além de um monótono estribilho - violência e segurança na perspectiva juvenil. $O$ caso de São Leopoldo. São Leopoldo: CEBI, 2009; $A$ volta ao sagrado e a espiritualidade juvenil (com Susanna Rocca). In: Aconselhamento Pastoral e Espiritualidade Juvenil. HOCH, Lothar; HEIMANN, Thomas (Orgs.). São Leopoldo: Sinodal, 2008, p. 143-164; A vivência religiosa dos jovens da Diocese de Montenegro (com José Silon Ferreira e Luis Alexandre Cerveira). São Leopoldo: Oikos, 2011; Acompanhamento, Juventude e Construção de Autonomia. (com Carmem Lúcia Teixeira e Lourival Rodrigues). Goiânia: PUC-GO, 2011. Em 2013 publicaram o trabalho de conclusão do Curso de Filosofia, de 1962, onde colaborei ativamente. Este trabalho foi feito junto com três outros companheiros jesuítas: síntese de duas tendências - A propriedade nas Reduções do Paraguai (com José Odelso Schneider, Guido Aloys J. Kuhn e Egídio Schwade). Porto Alegre: SESCOOP/RS, 2013. Em 2014 saiu Juventudes e Adolescências na Sociedade Leopoldense - Invisibilizadas? Cuidadas? Criminalizadas? São Leopoldo: CEBI 2014.

A juventude e a educação na fé dos jovens foram a minha "especialidade", isto é, minha preocupação. Por isso: "Lo Divino en el Joven - Reflexiones sobre la teologia del joven", Lima: IPADEJ, 1997; "Pastorales Especificas de Juventud”, Lima: CEP, 1996; "O Imaginário do Jovem do Rio Grande do Sul - leitura dos dados de uma pesquisa”, número especial da Revista PJ a Caminho, n. 67, 1997; Pastorais específicas de juventude, Porto Alegre: Evangraf, 1993; JEC no Brasil - uma proposta que não morreu, São Paulo: CCJ, 1992; O Divino no Jovem Reflexões sobre a teologia do jovem, Porto Alegre: Evangraf, 1997 (com várias edições); Civilização do Amor - tarefa e esperança. São Paulo: Paulinas, 1997 (co-autor e tradutor); Passos na travessia da fé. Goiânia, 2005 (coautor e revisor); Cartas a Neotéfilo. São Paulo: Loyola, 2003. Projeto de Vida, Goiânia, 2005. (coautor e revisor); Marcando história - elementos para construir um Projeto de Vida, Goiânia, 2005 (coautor); Acompanhamento - Mística do Acólito da Juventude. São Paulo: CCJ, 2008 (junto com Carmem Lúcia Teixeira e Salvador Segura Levy); Articulações Juvenis Católicas da América Latina. In: TIRELLI, Janice; GROPPO, Luis A. (Orgs.). Dilemas e Contestações das Juventudes - no Brasil e no mundo. Florianópolis: UFSC, 2011, p. 327374; Cartas de Francisco aos Jovens. São Leopoldo: CEBI, 2013; Mínimo do Mínimo para anunciar uma boa-nova à juventude. Curitiba: Instituto Ciência e Fé, PUC/PR, 2013; Silêncios e barulhos da juventude latino-americana. São Leopoldo: Editora UNISINOS, 2015 evidentes - os jovens construindo juventude na história (pela novidade e pelo atrevimento); Mística do acólito da juventude; Acompanhamento, Juventude e Construção de Autonomia (assunto que desafia a Igreja e a sociedade); $O$ Divino no Jovem - Reflexões sobre a Teologia do Jovem (pelo que consegui dizer); Cartas a Neotéfilo (um assunto ao qual me dediquei muito).

\section{NA CASA DE MEUS PAIS}

Nasci para a juventude aos 37 anos, no Rio de Janeiro; nasci para o mundo em Linha João Alves, na Travessa Dona Leopoldina, no município de Santa Cruz do Sul, no dia 12 de maio de 1937. Nasci em casa, à moda das parteiras em extinção. Nem tenho fotografia de mim ou de minha casa de quando menino. Hoje volto a casa em que nasci vendo-a reformada e diferente. Talvez mais bonita. A "velha cozinha", onde eu era banhado e tomava banho num tacho enorme, não existe mais. É uma pena!

Fico olhando a foto de minha família, de 1955. Somos 8 irmãos vivos; dois morreram pequenos, depois de mim. Sou o terceiro filho, precedido pelo Lauro e o Otmar. Depois de mim vem a Ilse (que se tornou Irmã Franciscana), o Eugênio, a Iracema, o Aldino e o Humberto (o mais novo). O caminho de cada um de nós foi muito diversificado.

Aprendi a ler, a escrever e a falar português numa escolinha de Linha João Alves, distante uns três quilômetros de casa. Para lá íamos a pé, de chinelo ou tamanco, dependendo do calor ou do frio. O professor foi Arthur Guilherme Rauber, que me marcou na vida e na vocação. Como meninos daquela "linha", jogávamos bola, atirávamos pedras uns nos outros, mas éramos muito amigos, íamos para a catequese quando o padre visitava nossa capela. Havia padres que eram brabos, outros não tinham jeito (até bebiam), mas quem ficou na memória, de fato, foi o Pe. Felix Darup, S. J., que vinha de charrete e com o qual ríamos muito e aprendíamos pouco. Aliás, para a minha Primeira Comunhão decorei a resposta de 241 perguntas e fui aprovado. O importante não era a vida, mas saber de cor aquelas coisas...

Santa Cruz do Sul, RS - a cidade - para mim, como criança, era uma região com casas aqui e acolá, mas era, principalmente, a casa de dois tios que moravam por lá e a Igreja matriz linda e enorme que via aos domingos e que, mais tarde, viraria Catedral. Visitando um dos tios que morava na cidade, o que me espantava eram as fábricas de fumo... A altura das torres da igreja me impressionava. Aos domingos, quando não chovia, eu, meus irmãos e minha mãe caminhávamos cinco quilômetros para "assistir" à missa. $\mathrm{O}$ pai ia mais tarde, a cavalo. Saíamos bem cedo para, na volta, fugirmos do calor. Não raro encontrávamos a igreja ainda fechada, no silêncio da manhã e da neblina. No inverno era duro. Se a estrada estava barrenta, carregávamos os sapatos até perto da cidade, onde havia uma fonte. 
Passando aí lavávamos os pés e calçávamos os sapatos porque, afinal, ir à missa era uma solenidade. E encontrávamos a igreja enorme. Ela era enorme, com um péssimo serviço de som. O padre falava lá de cima do púlpito e a gente quase não entendia nada. Um cantor, sozinho, lá no coro, parecia um coral. Terminada a missa, íamos à padaria Muller, na esquina. Comprávamos um pedaço de cuca para tomarmos nosso café da manhã porque estávamos de jejum, assim como a Igreja exigia. Na volta, no caminho, vinha o povo da nossa Linha para fazer o que já havíamos feito...

Minha língua materna foi o alemão de Santa Cruz. O português, nós - também eu - o aprendemos na escola, a partir dos 7 anos. Se meu pai arranhava um pouco de português, minha mãe nada disso. $\mathrm{E}$ os dois eram nascidos e criados em Santa Cruz do Sul, terra de imigrantes alemães. Por parte do pai, só conheci a avó porque meu pai ficou órfão ainda pequeno. Foi meu trisavô que veio da Alemanha. Pequeno, eu ia passear com minha avó Gertrudes nos amigos e amigas que ela tinha. Não me esqueço da tempestade que nos pegou, certa tarde, caminhando na estrada. Ainda hoje escuto os trovões e sinto o vento assobiando, aumentando meu medo. A primeira vez que vi meu pai chorar foi na morte dessa avó.

Da parte da mãe conheci o avô e a avó e os muitos tios e tias. Moravam na Linha Santa Cruz, a certa distância. Talvez uns 7 quilômetros. Era uma festa quando o pai arrumava a carroça para visitá-los, não esquecendo os "bancos" cobertos de pelegos. $\mathrm{O}$ avô materno era careca que nem eu e muito disposto. A visita dele sempre era uma alegria.

Éramos pequenos agricultores. Primeiro, o pai plantava fumo e todos ajudávamos. Depois, tornou-se um vendedor de hortaliças na cidade. Todos lá em casa trabalhavam. Quem ia para a cidade vender nossos produtos, contudo, era o pai. Só ele. Éramos pobres, mas nunca passamos fome. Desde pequeno fui acostumado a mexer com a terra, tratar os animais, colher milho, feijão, batatinha. Até ajudava a mãe a tirar leite das vacas. Voltando para casa, da roça, à noitinha, com a enxada nas costas, entoávamos cantos que íamos aprendendo. A mãe gostava disso. Sei que o cansaço era esquecido quando se ouvia, ao longe, no sino da nossa capelinha, o toque da Ave Maria.

Infância simples, de trabalhos, de estudos, de brincadeiras e de brigas de criança. Gostava de construir casinha... Só muito mais tarde me dei conta que uma das brincadeiras que inventávamos, eu e minha irmã (logo depois de mim), era rezar missa. Nunca vou saber por quê... Aos domingos, vinham os filhos dos vizinhos e de outra gente e arrumávamos maneiras de passar a tarde correndo por diferentes espaços, avançando em bergamoteiras e frutas do conde que havia, especialmente no mato, jogando pega-pega e outras coisas. O futebol veio mais tarde. Coisas de inocência e de alegria, de amizades e briguinhas quase sempre normais. 


\subsection{Quem é minha mãe?}

Minha mãe é uma santa. O nome dela é Josefa Paulina Rabuske (28/03/1908 a 21/o8/1988). A vivência de fé de mamãe era profunda, simples e coerente. Todas as mães são bonitas, mas minha mãe era muito bonita. Foi com ela que aprendi a rezar e a ser forte, mesmo nos grandes sofrimentos. O relacionamento dela com o pai foi muito bom, em geral, mas houve uma época terrível. No fim da vida, o pai não sabia viver sem ela... Apesar de ela ruminar, escondida, sua dor, sempre tinha um sorriso nos lábios. Além de tudo, ela foi discreta. Até na maneira de morrer ela foi discreta: não avisou ninguém e partiu nos braços de uma neta que não sabia o que fazer. Eu estava em Recife e viajei numa noite, pesando sentimentos. Não sabia o que era perder a mãe e era o primeiro encontro mais próximo com a morte. Quem me esperou no aeroporto, em Porto Alegre, foi o Pe. Ivo Bersch que, de imediato, me levou para Santa Cruz. Embora se alegrasse com o meu sacerdócio, foi minha mãe que mais se opôs à minha entrada no seminário.

Lembro-me dela indo com a gente para a igreja; lembro-me dela puxando o terço, principalmente aos domingos, quando não podíamos ir à missa porque chovia; lembro-me das comidas que fazia; lembro-me do orgulho que tinha dela. Tantas coisas... Não podiam faltar, em casa, as leituras em alemão. Divertia-se demais com as histórias do Pe. Balduíno Rambo, em alemão dialeto. É santa Paulina, com certeza. Ela morreu sem avisar. Teve um ataque fulminante. Viveu sem incomodar e morreu sem incomodar.

\subsection{Pai a ser honrado}

Meu pai era de outro gênio: João Dick (01/03/1909 a 06/01/1987). Filho de Gertrudes Lersch Dick (27/08/1869 a 08/10/1945) ficou órfão muito cedo. O pai dele, José Dick, (26/08/1861 a 01/o8/1918) faleceu quando meu pai tinha apenas 9 anos. Ficou cuidando da mãe, minha avó, morando na mesma terra. Embora não deixasse de ir à missa (a cavalo, quase sempre) e rezar conosco o terço nos domingos de manhã, era mais reservado (frio) que a mãe. Trabalhador. Sério. Aparentemente duro, não posso esquecer o choro dele quando eu partia para o Seminário. Quase não podia acreditar que meu pai soubesse chorar. Lá em casa o carinho não era beijo, nem abraço. Um aperto de mão valia muito. Sei que beijei minha mãe bem mais tarde, quando já era jesuíta. Meu pai morreu no hospital, nos meus braços e no de meus irmãos. Nos últimos tempos de vida estava muito doente. Ia e voltava do hospital. Quando ele morreu, eu estava em férias no Recife. Quando viajei, naquela vez, lembro-me que viajei com aquele sentimento estranho que enterraria meu pai... E aconteceu mesmo. Quando o encontrei na cama, deu-me a impressão que ele estava esperando me ver para partir. Dois dias depois o acompanhava, ajudando-o a "nascer" tranquilo para a eternidade. 
O pai criou-nos um pouco na dependência. Sofreu muito quando assumimos a questão do futuro e da herança. Foi difícil explicar para ele que assim seria melhor. Guardo dele, no meu caráter, certos momentos de rancor e de melancolia. Lutou muito, e era um orgulho ver cada um de seus filhos se fazendo na vida. Quando celebrávamos a missa de corpo presente foi lindo ver como as netas enfeitavam o corpo do avô.

Como seminarista e como jesuíta vivi muito longe da família. Passei cinco anos no Rio de Janeiro, quase três anos em Brasília e quase sete anos em Recife, sem falar dos anos que estive em Montenegro, São Leopoldo e Porto Alegre. Os encontros se davam nas férias. Quem reclamava muito eram o pai e a mãe. Meus amigos de infância, com os quais estudava (sempre gosto de rever a velha escolinha onde aprendi as primeiras letras) e com os quais passava os domingos de tarde, me acompanham de longe, com a simplicidade que os caracteriza. Nos raros momentos em que os encontro vejo neles aquela vontade doida de conversarem sobre a vida que levo, mas se inibem e ficam, na maioria das vezes, numa sorridente saudação. Uma das coisas que sinto, voltando para a minha terra, é a vontade de falar o alemão que aprendi na infância e comer a linguiça que meus pais faziam.

\section{SEMINÁRIO, LOUCURA?}

- Por que você ficou padre?

É uma pergunta que escutei e escuto muitas vezes, no trabalho com jovens. Falando da fase de minha vida em que entrei no Seminário Menor, não escapo de contar algo que sucedeu comigo aos 11 anos. Estávamos na escola da Linha João Alves quando, pelas 10 horas da manhã, entrou na escola o Pe. Felix Darup. Ele fazia isso mais vezes. Descia da charrete (não havia fusca e muito menos "gol") e batia um papo bobo, mas descontraído com a criançada. Nesta manhã, contudo, ele inventou de perguntar:

- Alguém de vocês já pensou em ser padre?

$\mathrm{Eu}$, com mais alguém da turma, com a espontaneidade da criança, levantei o braço. Não era algo inocente... e a notícia não ficou aí. Meus irmãos (estávamos aí em três) se encarregaram de levá-la, inclusive, para casa. O Pe. Felix era um velho simpático. Fumava um cachimbo que não podia deixar de chamar a atenção. Era ele, também, responsável pelos seminaristas jesuítas de Santa Cruz do Sul. Sei que a coisa mexeu em mim e a coisa tornou-se séria. Ainda mais quando o padre veio falar com meus pais. E fui... Mas não era só ele. Era, também, aquela coisa diferente que os padres jesuítas (que atendiam a nossa região) deixavam no ar. Começando a entrar na casa paroquial, ao mesmo tempo em que me assustava, confirmava sentimentos interiores. Seria injusto, se não me referisse, neste assunto, ao contexto familiar. É claro que ele ajudou. Mesmo que ninguém forçasse a barra, a ideia de ser padre era bem vista. 
Não como promoção humana, mas como bênção de Deus. Ter um filho padre, na minha região, era uma graça. Compreender este aspecto parece-me muito importante. Embora tenha resquícios de cultura, é algo mais profundo onde a fé tem segredos que nem sempre se adivinham.

- Isso explica alguma coisa?

Acho que não. Dá pistas para entender melhor um mistério. Por que, como crianças, gostávamos de brincar de assuntos religiosos? Alguém nos instigara? Num cantinho da casa, com a maior das solenidades, eu e a Ilse (nem estávamos na escola), rezávamos missa... Sei que em 1949, sem ter completado 12 anos, partia para o Seminário. A Ilse é a Irmã Ilse, franciscana da penitência e caridade cristã.

- Loucura!

Se foi loucura, ou não, quem é que pode dizer? Olhando os prédios enormes da Escola Apostólica, em Salvador do Sul/RS, minha reação é calma e saudosa. De vez em quando vou lá para lembrar... Podem chamar-me de doido, mas meu tempo de Seminário foi muito bom. Não faltaram saudades e muitos colegas meus não aguentaram. Minha adolescência ficou naqueles cantos, naquelas salas, naqueles dormitórios enormes, naquelas paisagens que me levavam para longe... Ocupações é que não faltavam: estudo, trabalho, jogo. Momentos "gloriosos" eram os passeios que fazíamos, caminhando mais de dez quilômetros. A gente acampava, cozinhava, fazia jogos de guerra. Era uma festa. E como esquecer a formação de escoteiro? O Irmão Vicente Slany era muito divertido e um educador de mão cheia. Artista doido, mexia com todos nós. Pintava de tudo, fazia cenários para os teatros e dava aulas de desenho.

\subsection{Coisas de seminário}

A certa hora da tarde, no calor ou no frio, lá íamos, todos nós, para a piscina, a quinhentos metros do Colégio. Todos tinham que aprender a nadar. Uma festa que se destacava era a festa de Santo Inácio. Além do teatro solene, era o dia em que os pais vinham de visita. Além de outras atividades mais religiosas, o Grêmio Literário funcionava, de fato, girando em torno de assuntos os mais variados, estimulando a leitura. Além de História de uma alma, de Teresa de Lisieux - no aspecto espiritual, os livros de Tihamer Toth, no aspecto afetivo-sexual, líamos as aventuras de Karl May com Winnetou e outros na perspectiva do lazer. Lembro-me do pessoal declamando poesias, do Emir Calluf tocando piano, do coral de mais de cem vozes cantando em português e alemão. Além das comédias e dramas a que assisti, recordo a peça teatral onde trabalhei como superior das reduções dos jesuítas do Paraguai: Assim na terra como no céu. Morri como quem tinha sabor de missionário espanhol...

As grandes devoções eram o Apostolado da Oração e a Congregação Mariana. Para cultivar a devoção ao Coração de Jesus os "padres espirituais" estimulavam o controle 
de todos nós em praticar atos de devoção (terço, via-sacra, visitas ao Santíssimo...). No fundo dos pátios do Colégio, com uma linda paisagem por cima dos vales cheios de névoas, estava uma estátua de Maria Santíssima onde a gente se encontrava para rezar o terço e realizar "serões marianos", em geral, de grande beleza.

E assim foram passando oito anos de Seminário Menor. A adolescência ficou aí: bonita, ingênua, sabendo saborear o horizonte e os sonhos. Nas aulas nunca fui o primeiro, mas sempre estava entre os primeiros. Formei-me no segundo grau em 1956. Dos treze colegas que tive no último ano, três são jesuítas e dois do clero diocesano. Meu sonho, nesta época, com toda a sinceridade jovem, era ser padre. E houve figuras que me impressionaram muito, mesmo que tenham deixado a carreira sacerdotal. Ao partir para o Noviciado fazia-se sempre uma grande festa de despedida e coube-me fazer o discurso dos que iam para o início da vida religiosa. Não me esqueço de que quando acabei de ler Diário de um pároco de aldeia, de Georges Bernanos, era uma tarde fria e chuvosa, como no romance. E chorei... Vibrei, contudo, com o final do romance dizendo que "tudo é graça".

\subsection{Convento? Nem tanto}

Em fevereiro de 1957 entrava, pois, no Noviciado da Companhia de Jesus em Pareci Novo-RS. Foram dois anos, onde a grande experiência foi o retiro de trinta dias que fiz da maneira como minha estrutura interior permitia. Sei que entrei numa crise de vocação: não me achava digno; tinha vontade de ser pai e constituir família; achava que não queriam que fosse jesuíta etc. Uma crise da qual me lembro para agradecer.

No tempo do Noviciado houve coisas exóticas como jogar voleibol de batina, flagelar-se, dizer a culpa no refeitório, almoçar ajoelhado etc. Fiz os votos de religioso e comecei a etapa chamada de "Juniorado": um tempo de cultivo das "humanidades". A leitura dos trágicos gregos mexeu comigo e o Pe. Victor Steffen incentivou-me no amor às letras. O desejo de ser padre enriquecia-se, aos poucos, com o desejo de ser padre-crítico literário. Era, porém, um sonho vago e ainda inconsistente.

\subsubsection{Humanidades...}

Vivíamos um tempo de muita mudança no currículo de formação dos jesuítas e comunicaram-nos que partiríamos mais cedo para a Filosofia, em São Leopoldo. Éramos um grupo de cerca de trinta estudantes. Apesar da boa convivência, dos jogos animados de voleibol (eu era um jogador bastante bom), dos passeios, das catequeses, das rezas, da experiência de ter um "anjo" que te acompanhava para animar e criticar, foi-se o tempo de Pareci Novo. 


\subsubsection{Filosofia}

Dos anos de Filosofia (1960 a 1962), em São Leopoldo, sei que foi um tempo bom, de muito estudo, de vida tranquila e não muito mais. Os professores variavam de ótimo a péssimo. As figuras dos professores Lourencino Puntel, Delmar Schneider, Cirne Lima foram marcantes. Pelo lado pedagógico de "acompanhantes", recordo o Pe. Frederico Laufer e o Pe. Géza Koevecses. Sei que eu não brincava de estudar. Respirava-se no ar a necessidade de mudança, mas sem saber dizê-lo. O Vaticano II não havia acontecido, mas pressentia-se que algo deveria acontecer na sociedade e na Igreja.

Só mais tarde, na pós-graduação na Universidade Federal do Rio de Janeiro, senti a importância de ter-me esforçado em ser bom estudante de Filosofia. As próprias pirraças com professores e colegas eram normais. Lembro que, para meditar, eu escrevia. Cadernos e mais cadernos dos quais me desfiz muitos anos depois... Era o jeito que encontrei para rezar. O local onde estávamos chamava-se Colégio Cristo Rei, um prédio enorme de mil utilidades. Além dos estudantes de Filosofia, havia setenta estudantes de Teologia vindos de muitos lugares do Brasil e do mundo. Um aspecto a recordar é o ingresso, na vida religiosa, de diferentes tipos de atendimento psicológico: o clima dizia que era de bom tom fazer terapia... Quem não fazia terapia era quase um jesuíta de segunda categoria, mas não considerei importante ou necessário embarcar nesta onda.

\subsubsection{Magistério}

Terminados os três anos de Filosofia, fui para o "Magistério" (tempo de inserção em algum apostolado) na Faculdade de Filosofia, Ciências e Letras de São Leopoldo, aluno do Curso de Letras. Três anos cheios de variedade. Apesar de minha consciência ingênua (nem havia compreendido nem assimilado o golpe civil-militar de 1964) fui um militante ativo no Diretório Acadêmico. Coube-me o Departamento Cultural e editamos muitos números do boletim que intitulamos $O$ Reaça. Uma iniciativa que teve projeção e nos levou para várias cidades do interior foi o teatro. Constituímos um grupo que apresentava várias peças. Uma delas foi Testemunha da Acusação e a outra O Labirinto, escrito por um dos nossos atores, estudante de História: José Baldissera. Como aluno do Curso de Letras dava aulas de Ética no curso de Ciências Sociais. No final de 1965, a revista da cidade Rua Grande indicou meu nome como um dos "Destaques do Ano" da cidade por causa do fomento ao teatro.

Participei (sem muito preparo) de um grupo da Juventude Universitária Católica (JUC) e das discussões nacionais, em 1963, da Reforma Universitária, debate promovido pela União Nacional dos Estudantes e formei-me em 
Letras no final de 1965. Fui o orador da turma. Tinha 28 anos. Além das atividades e dos estudos, fui chamado para lecionar Literatura Brasileira no Colégio Anchieta, em Porto Alegre, substituindo um professor que os alunos haviam, praticamente, demitido da sala de aula. Foi meu primeiro contato com a sala de aula cheia de adolescentes vislumbrando a juventude.

Confirmando meu desejo de ser crítico literário, participei, em 1966, em Montevideo, do $10^{\circ}$ Instituto Linguístico Latino-Americano. Era a primeira vez que saía de terras brasileiras. Lembro-me do Prof. Rona, do Prof. Prieto, do Prof. Leodegário Azevedo e outros. O que me impressionou (era tempo de Natal) foi passar aqueles dias carregados de espírito de Belém sem perceber nenhuma manifestação visível da festa nas ruas... Como "Mestre" no Colégio Anchieta, em Porto Alegre, passei um ano de contradições: assim como tive uma ótima convivência comunitária, (Paulo Englert, Osvaldo Leite, João Roque Rohr, Adriano de Marchi, Franz Stadelmann, Pe. Manoel Flach etc.), tive que suar a camisa para dar, como marinheiro de primeira viagem, aulas de Literatura Brasileira, de Literatura Portuguesa, de Literatura Latina e Grega e de Teoria Literária. Contudo, no final de 1967 fui premiado como professor num concurso realizado pela Livraria Agir (Rio de Janeiro), tirando através de trabalhos de meus educandos do Anchieta - o $1 .^{\circ}$ e o $3 .^{\circ}$ lugar. Além de receber uma máquina de escrever "Olivetti", recebi como prêmio, também, uma viagem por grande parte do Brasil. Pela primeira vez viajei de avião, visitando Rio de Janeiro, Brasília, Belém, São Luiz do Maranhão, Teresina, Recife e Salvador.

\subsubsection{Teólogos atropelados}

De 1967 a 1969 fiz meus estudos de Teologia, em São Leopoldo. Como eram os primeiros anos depois do Vaticano II, os professores se esforçavam em se ajustar, ao máximo, aos novos ventos provindos do Concílio. Foram os anos em que a repressão política da ditadura baixou firme em todos os cantos do Brasil. O "Colégio Cristo Rei", onde fazia minha Faculdade de Teologia, foi considerado - num certo momento - como um foco de subversão. Quando os militares quiseram prender Frei Betto (colega de estudo), não tiveram dúvida em invadir nosso prédio com todas as grosserias de uma conquista policialesca. Não encontrando Frei Betto, outros foram levados para serem interrogados.

Como jesuítas, 1968 foi importante não só pela experiência da repressão política, mas porque, no dia 4 de maio deste ano, chegava em Porto Alegre o Pe. Pedro Arrupe, Geral da Companhia de Jesus, afamado por suas posturas em favor da libertação. Apresentamos-lhe um longo trabalho sobre a formação jesuítica e tivemos um ótimo e acalorado debate sobre a vida na Companhia de Jesus. A efervescência política e teológica, também neste encontro, foi 
muito grande. Foi a época em que os religiosos (também os estudantes de Teologia) começaram a abandonar as grandes casas de formação para se inserirem em residências simples, na periferia das cidades.

\subsubsection{Muita coisa...}

Ainda hoje fico admirado de como fui capaz de assumir tantas frentes durante a Teologia, sem deixar de ser um bom estudante. Nunca parei para refletir sobre o que vivemos naqueles anos, mas foram anos de impressionante intensidade. Recordar colegas de várias culturas e nacionalidades exigiria espaço, mas não quero deixar de citar Gilles Bernier, Paulo D’Elboux, Marcel Messier, João Roque Rohr e, de modo especial, meu colega e companheiro de "peregrinação" no Noviciado, Afonso Fleig, amante de Saint-Exupéry, formado em Agronomia e que morreu, poucos anos depois - como padre - debaixo de um jipe, no interior da Bahia.

Em setembro de 1968 aconteceu o que caracterizaria minha vida: um encontro de jovens em Osório-RS. A convite de antigos alunos e do Pe. Armando Marocco fui participar de um encontro nacional de estudantes marianos, em São Paulo. De jeito nenhum desconfiava que estava entrando nos passos da trilha que, cinco anos depois, abraçaria como uma das causas de minha vida.

No último ano de Teologia, em 1970, apresentou-se uma oportunidade de substituir o vigário da paróquia do centro de São Leopoldo. Uma das atividades de então foi a realização na Praça em frente à Casa Paroquial, de uma "Feira Intercolegial de Livros", com a meninada tomando conta das barracas abarrotadas de livros, tornando-se vendedores de cultura. Com o fato de ser professor na Faculdade e o Pe. Gilles Bernier ser do Diretório Central de Estudantes, a Casa Paroquial virou um viveiro de gente, especialmente de jovens universitários.

\subsection{Rio de Janeiro e um novo Hilário}

Meu sonho era, ainda, ser crítico literário e, por isso, no final de 1970 partia para o Rio de Janeiro (Rua São Clemente 226 - Botafogo), de 1971 a 1975. Outro Hilário foi nascendo aos poucos, sem eu me dar conta. Fui ao Rio na certeza de já estar admitido no Mestrado em Literatura Brasileira, nem pensando em voltar... Sempre acostumado a ter as coisas prontas, vi-me sozinho numa metrópole. O primeiro susto foi o inesperado exame de seleção. Em menos de uma semana, tive que fazer o que dava e ir para os exames. Eram mais de 100 candidatos para 27 vagas. No exame de Linguística os candidatos se levantaram, falando grosso com os que aplicavam o exame. Fiquei quieto no meu canto, resolvendo o que dava. Dá para imaginar o "suspense" que vivi esperando o resultado. 
Os primeiros anos se resumiram em estudar, participar de grupos de estudos e ir para a aula. Tinha consciência clara que era para isso que estava aí. Em 1973, no entanto, um grupo de rapazes e moças me vieram dizer que faltava um padre para trabalhar na coordenação dos grupos de jovens do Vicariato Sul do Rio de Janeiro (haviam-me conhecido num e noutro encontro do TLC - Treinamento de Liderança Cristã). Fui claro em afirmar que minha prioridade era o estudo. Assumindo, porém, este trabalho, iniciei a visitar os grupos de jovens. Foi gostoso e, aos poucos, os encontros de entrosamento e de formação foram acontecendo. Acompanhava-me, nisso, uma equipe muito amiga e muito disposta. Nunca tinha estudado "Pastoral da Juventude", nunca participara de algum encontro onde o assunto fosse a forma de os jovens se organizarem, mas estava aí, animando e procurando a melhor forma de este pessoal crescer na fé. Comecei a perceber que tinha jeito de "articular", isto é, fazer que os jovens tivessem vontade de se encontrar para trocar experiências. Creio que o melhor resultado se deu em 1974, por ocasião da preparação para o Ano Santo. Os jovens da Zona Sul do Rio de Janeiro foram os únicos (além das Religiosas) que fizeram uma "peregrinação". Num sábado à tarde, num dia cheio de sol, saímos da Praça Tiradentes (centro do Rio) até a nova catedral do Rio. Éramos uns 4.00o jovens cantando, fazendo paradas de reflexão e concluindo, no final, com uma Eucaristia presidida pelo Cardeal Dom Eugênio Sales. Havia mais de 50 violeiros tocando, formando uma orquestra.

\subsubsection{O café da juventude}

Todas as quartas-feiras, à noite, um grupo de 50 a 100 jovens se encontravam na Rua São Clemente para aprofundarem a sua fé. Era a "Escolinha da Fé" que o pessoal começou a chamar de "CAFÉ" (Curso de Aprofundamento na Fé). Foram eles que me questionaram: "E você, quando voltar, vai se fechar num gabinete para ser Chefe de Departamento na Faculdade?" Todos sabiam que, terminado meu Doutorado, voltaria para o Sul. Antes de isso acontecer, começaram a organizar um abaixo-assinado de mais de 2.00o jovens, dirigido ao meu Superior Geral (em Roma), pedindo para eu permanecer no Rio de Janeiro. A missa de despedida foi na igreja Santo Inácio, em Botafogo, cheia de jovens. Tenho comigo o sermão que fiz e tentei ler, mas não consegui. Leu-o um colega meu. Falei de coração.

Uma questão delicada que me colocava, a partir de 1973, foi a questão do tipo de padre que desejava ser. Por que não assumir o ministério sacerdotal dentro da Universidade? Depois de muitas idas para a Casa de Retiros da Gávea, decidi abraçar a opção de largar o doutorado em Letras e ser educador de jovens fora da sala de aula. Foi uma opção que meus companheiros, só depois de 37 anos, aceitaram. 
Voltei ao Rio em 1977 para defender a minha tese: "Função Estética da Natureza na Poesia Romântica Brasileira". Afrânio Coutinho era meu orientador. Eduardo Portella e Cleonice Berardinelli estavam na banca. Em 1975 publicara meu primeiro livro para jovens: Na busca de ser - a angústia de não ser. O título foi sugestão de uma menina com a qual ri de montão. Logo depois, baseado em grande parte na vivência tida com os jovens do Rio, escrevi Deus é Devagar. Eu tinha nascido para a juventude há quatro anos.

\subsection{Viradas importantes}

\subsubsection{Teologia da libertação}

Foi no final de 1975, em São Leopoldo, que comecei a vislumbrar o que seria Teologia da Libertação, prestando um exame de Teologia. Algo indescritível! Em segundo lugar, uma síntese teológica que escrevi junto com o Pe. Francisco Taborda intitulada "Creio na liberdade". Minha destinação era o "Centro Religioso" da UNISINOS. Mesmo com certo desgosto, os jesuítas aceitaram, mas diziam que não conseguiria resultado. No inverno daquele mesmo ano estava coordenando um primeiro encontro de universitários na Vila Betânia, em Porto Alegre. São Leopoldo era, na época, uma grande pensão de estudantes. Mais de quatro mil jovens vinham de fora para estudar e viviam em repúblicas de muitos tipos. Minha vida noturna, por um bom tempo, foi visitar estas pensões, maiores e menores, de meninos ou de meninas. Conversava, tomava cachaça com eles e, tempos depois, rezava missa com eles. Só isso explica porque a "missa universitária" teve tanto sucesso na capela do Rosário.

É verdade que em Porto Alegre estavam acontecendo os encontros de impacto chamados "Emaús" nos quais trabalhei uma e outra vez, a convite. Via, contudo, que não era isso que se fazia necessário. Com a assessoria teológica do Pe. Francisco Taborda e de alguns estudantes de Teologia, partimos para outra dinâmica. Formaram-se vários grupos de universitários que, mais tarde, seriam a semente da "Pastoral Universitária". A prova de que a iniciativa chamou a atenção não só dos universitários, mas de toda a comunidade leopoldense é que no final de 1976 fui escolhido outra vez como "Destaque do Ano" sob o ponto de vista religioso. Foi durante a missa universitária que, em 11 de junho de 1978, professei meus "últimos votos".

\subsection{2 "Serviço religioso"}

Trabalhei na UNISINOS de 1976 até o final de 1978. Era o coordenador do "Serviço Religioso". Fizemos coisas bonitas com os funcionários (entrosamentos, passeios, jogos, celebrações etc.), mas o trabalho com os alunos 
chamava mais atenção. No início de 1977 fui nomeado um dos sete Diretores da Universidade, responsável pelos Órgãos Complementares (Biblioteca, Teatro, Coral, Psicologia, Serviço Religioso, relacionamento com os estudantes etc.). Até fui chamado para subir no estrado dos estudantes na primeira greve dos estudantes da UNISINOS... Apesar de ser um dos Diretores da Universidade, os conflitos com a administração central foram crescendo, principalmente através do boicote de iniciativas. Sei que cansei e falei com o Provincial, Pe. Paulo Englert, da vontade de sair da Universidade. Ele não concordava e pediu que fosse fazer um retiro e discernir o assunto. Depois disso falaria comigo. É o que aconteceu. Conversamos horas e horas para decidirmos que eu sairia da Universidade e que ele comunicaria isso à Reitoria. Saí da Universidade em final de 1978. Foi um dos discernimentos mais pormenorizados que fiz na minha vida. Minha destinação foi para a "Casa Padre Jorge" onde, durante um ano, animei a reflexão sobre o destino daquela Casa. Um ano depois surgia aí o IPJ (Instituto de Pastoral de Juventude), uma obra que sempre abracei de pés e mãos. Foi a menina dos meus olhos de pastoralista e de assessor de jovens. Todos se lembram de que 1979 foi o ano da opção preferencial pelos pobres e pelos jovens na Igreja da América Latina. Saindo da UNISINOS não deixei de ter minha ligação com os grupos de Pastoral Universitária espalhando-se por todo o Brasil. Tanto é que em 1980 fui escolhido como assessor nacional deles. Foi no IPJ que assisti e participei, com delegados de São Paulo, Paraná, Santa Catarina e Rio Grande do Sul, de um primeiro debate profundo e pioneiro sobre a Pastoral da Juventude segundo os meios específicos.

\subsubsection{Ano agitado}

1981 foi um ano muito agitado, ficando claro meu desejo de acentuar a participação de um Comitê Latino-Americano do MIEC-JECI, em Lima (14 a 28 de março). Com o apoio da Equipe do IPJ fiz, na mesma ocasião, uma viagem por vários países da América Latina para observar o trabalho com a juventude. Fui, por isso, para o Equador, Colômbia (Casa da Juventude), Chile (ISPAJ), Argentina e Uruguai. Um local que fiz questão de visitar, naquela viagem foi Riobamba (Equador) onde era bispo D. Proaño, "pai dos índios" e local de referência de toda a América Latina. Um fato que desejo recordar é que a imprensa inventou de "dar em cima" do IPJ, logo no início de sua existência... Nos mesmos dias apareceram artigos e reportagens sobre a "escola que prepara jovens para o socialismo" (assim que falavam) em Fortaleza, no Rio de Janeiro e em Porto Alegre. A "coisa" parecia tão séria que "O Estado de São Paulo" publicava duas páginas inteiras sobre o IPJ. O segundo fato se refere à vinda ao IPJ de D. Cláudio Hummes, encarregado do Setor da CNBB, à procura de alguém que pudesse fazer o serviço de assessoria à Conferência no Setor Juvenil. 
A Província dos Jesuítas do Brasil Meridional liberou-me por quatro anos e lá fui eu.

\subsection{Tentando ajudar os bispos em Brasília}

Vivendo em Brasília, fiquei no Setor Juventude da CNBB de outubro de 1981 a junho de 1983. Em abril de 1982, no entanto, aparecera uma primeira manifestação estranha: D. José Romer, bispo auxiliar do Rio de Janeiro, publicara uma crítica violenta a um livreto compilado por mim e que procurava apresentar à Igreja o que era a Pastoral Universitária, da qual eu era o assessor. Falando com D. Cláudio Hummes, aconselhou-me valer-me da assessoria teológica do Pe. Francisco Taborda S.J. É o que aconteceu e não houve mais resposta do bispo. Enquanto isso, viajava pelo Brasil, tomando contato com lideranças e assessores de todo o país. O evento que considero mais significativo foi a realização do "Grupo de Trabalho" (setembro de 1982) e a elaboração de um documento sobre a evangelização da juventude no Brasil, tornado conhecido pelos bispos antes da Assembleia deles, no ano seguinte.

1983 foi um ano de eleições, dentro da CNBB, havendo mudanças no grupo de Bispos responsáveis pelos diversos setores e, consequentemente, no grupo de assessores que estavam dentro da CNBB. D. Cláudio Hummes foi substituído por D. Sinésio Bohn, que me conhecia. Pressionado, foi levado a me dizer, depois de muitas resistências, que eu não permaneceria no cargo de assessor. $\mathrm{O}$ fato é que, em junho de 1983, no meio do ano, tive que fazer as malas. Não me esqueço da conversa fraterna que tive com D. Luciano Mendes de Almeida na calçada em frente à embaixada de Portugal. Vi que a mosca azul do poder é muito venenosa, também no episcopado... Quando me vi "desempregado", meu Provincial pediu que descansasse porque - provavelmente - ele não sabia o que fazer comigo... Sei que havia várias possibilidades. Tudo estava encaminhado para ir a São Paulo, quando D. Paulo Evaristo Arns deu sua decisão: “- Não. Ele é muito radical..."

Nos inícios de agosto de 1983 o Padre Provincial me chamou e perguntou: "- Você teria vontade de ir para o Nordeste? Os jesuítas são tão poucos lá... Além de tudo, D. Cláudio Kolling não o tolera por aqui. Aceita?” Confesso que foi uma proposta que nunca imaginara na minha vida. O Nordeste era, para mim, ao mesmo tempo, terra sagrada e uma região onde havia experimentado - no trabalho com a juventude - as maiores oposições. O Provincial não sabia nada disso e me pediu duas coisas: que não deixasse de trabalhar com os jovens e que não fosse morar em João Pessoa-PB. E assim fui pegar minha "mudança" em Brasília.

\subsection{Banho de nordeste}

Em 31 de agosto de 1983, às 23:00 horas, chegava em Recife, sendo uma mistura de apóstolo e de exilado. $\mathrm{O}$ primeiro solavanco senti quando me disseram que, 
evidentemente, e com muita alegria, eu trabalharia na UNICAP (Universidade Católica de Pernambuco). Não vou ater-me à minha vivência nesta Universidade, em Recife. Uma primeira imagem que apresento se relaciona com a quadra coberta do Bloco A, quase cheia de estudantes, recebendo D. Helder Câmara. Era 1984. Como arcebispo de Olinda e Recife ele tinha sido, por longos anos, considerado persona non grata na Universidade. O Pe. Fred Sólon e eu resolvemos juntar as forças, quebrar o tabu e desfazer esta vergonha histórica. Foi numa missa de Páscoa.

Outra imagem relaciona-se com as Jornadas de Aprofundamento Universitário (JAU). Estas Jornadas de um dia inteiro, aos domingos, na UNICAP, exerceram um papel importante no sentido de recomeçar a mostrar a todos - professores, alunos e funcionários - que a Universidade carregava dento dela uma utopia e que ela não gostaria de ser, simplesmente, uma Universidade a mais. Lembro-me dos painéis enormes que o P. Fred preparava para chocar os que passavam colocando aí ilustrações que mostravam o monstro do golpe militar de 1964 e, ao mesmo tempo, figuras pornográficas chamando a atenção para a exploração sexual. Houve Jornadas com mais de 600 participantes.

Em 1985, Ano Internacional da Juventude, reunimos na quadra do Colégio Nóbrega (Recife) mais de 4 mil estudantes do ensino médio, para celebrar a juventude. $\mathrm{Na}$ mesma direção iniciou-se com a primeira celebração eucarística, presidida por D. Helder Câmara, a "Missa do Estudante”. Além disso, com a ajuda das Damas da Instrução Cristã meti o pé na estrada: Vitória de Santo Antão, Garanhuns, Nazaré da Mata, Campina Grande, Maceió, Fortaleza, João Pessoa, articulando uma pastoral estudantil. Foi um ano de santas loucuras que a juventude merecia. E a Pastoral da Juventude Estudantil do Nordeste caminhou, rápida, para a articulação nacional.

Se sempre investi numa articulação responsável e bem documentada, priorizei neste trabalho a preparação de assessores. Muitos encontros... Além das dificuldades que se encontravam nas direções e nos educadores tivemos que enfrentar várias dificuldades com outras pastorais. Por um lado, defendia-se uma Pastoral da Juventude organizada por classes sociais; por outro se acreditava que esta organização se dava por "categorias", imbuídas de uma consciência crítica e de classe. De 1986 a 1989 participei da Comissão Nacional de Assessores da PJE. Tenho consciência do que fui nesta Comissão, do que se realizou e do que se sofreu. Um dos frutos mais marcantes foi o encaminhamento dos Cadernos da PJE. Em nível de Recife, uma das contribuições que marcaram a PJE do Brasil foi a elaboração - em mutirão - dos Primeiros Passos oferecendo subsídios de como trabalhar pedagogicamente com grupos de estudantes.

Com essa vontade doida de construir o Reino no mundo da Educação, abracei outra militância, para mim estranha: a presidência da Associação de Educadores Católicos de Pernambuco. Sei o que vivi, viajando pelos interiores, 
lutando pela formação de núcleos de educadores, sentindo próxima a rejeição da proposta por parte de colégios de peso, sofrendo com a minha substituição. Houve figuras excepcionais nesta "guerra": Tedesco, Luciano, Glória, Luzy e vários outros. Um dos textos que escrevi com mais gana foi "Teologia do Educador". Consegui dizer o que outros, certamente, deveriam dizer com muito mais fundamento teológico, mas disse com alma.

\subsubsection{Despedida}

Aos solavancos, pois, e sem dizer nada de tudo que significou para mim o nordeste, chegamos em junho de 1990. Uma coisa que nunca esquecerei é o calor da acolhida nordestina e a vontade de ser, em meio às pequenas bobagens da vida, ajudando para que a vida fosse uma festa. Até a própria despedida. No dia 2 de julho partiria, portanto, para um tempo sabático onde desejava fazer três coisas: escrever a história da Juventude Estudantil Católica, conhecer o trabalho da Igreja com os estudantes da América Latina e fazer um curso de reciclagem em São Leopoldo. $\mathrm{O}$ resultado dessa viagem de sete meses pode ser encontrado em "Los estudiantes siendo Iglesia en América Latina - La historia de la JEC", publicado pelo Secretariado Latino-americano do MIEC-JECI (Quito). Foram sete anos e sete meses de grande riqueza.

$\mathrm{O}$ ato mais significativo da despedida foi a missa no Colégio São José. Lembro o Tedesco (presidente da AEC-PE) falando coisas que só a presença da juventude inspira. Entregaram-me um painel enorme com mensagens, das mais românticas às mais pornográficas. Conservo uma recordação nordestina muito querida. Assim como ir para lá foi uma viagem para um mundo vestido de mito, o sair de lá foi voltar às fontes onde nascera, numa cultura linda, mas muito diferente.

\subsection{Voltando ao ninho}

Voltando do ano sabático e depois de uma viagem a Europa, após o Comitê Latino-Americano do MIEC-JECI, em agosto de 1991 voltava para o IPJ de Porto Alegre, que ajudara a fundar nos anos de 1979 e 1980. Apesar de o nordeste ter-me proporcionado uma vivência muito feliz, voltei alegre para a missão para a qual o Provincial me enviava. A equipe também me recebeu com muita alegria. Era uma obra que encarnava minha causa... Por vários anos coordenei o Curso de Assessores de Jovens, de mais de 300 horas, em três etapas, em regime integral. No que conheço, foi o mais longo e o melhor Curso de Assessores da América Latina.

Em 1994 fui convidado, como assessor latino-americano do MIECJ-JECI, a participar de um Comitê Mundial do MIEC-JECI na Costa do Marfim. O encontro foi em 
Yamussucro, no interior, onde se encontra uma catedral maior que a Basílica de São Pedro; onde a Universidade em que o encontro se realizou era muito grande; onde não passei fome porque o cozinheiro me conseguia um mamão enorme na hora do café; onde fomos levados a visitar um Centro de Convenções de primeiro mundo, rodeado de casinhas de sapé. Tudo por amor à juventude.

Nestes anos todos, muita coisa foi marcante. Peço licença para recordar, especialmente, a Irmã Enedina Pierdoná que sempre achei bonita. Posso dizer que nos tornamos irmãos de sonho. Deus sabe o que conversávamos nas caminhadas pelo pátio, arrumando e comprando folhagens, ordenando o banco de dados, fazendo planos juntos. Ela era bonita de entusiasmo, de amor à juventude. Era bonita, mas não entendia muito de geografia; foi com ela que pusemos na entrada dos quartos, no primeiro andar, uma placa dizendo: "O IPJ é sua casa". A Dina era bonita de rezar. Foi com ela que na praia das Gaivotas, sentados em cadeiras velhas, que nasceu a ideia de "O divino no Jovem...”. No Instituto morava uma causa definida pelos jovens e isso se mostrava no planejamento e no cuidado com a casa em seu interior e exterior. Minha alegria foi enorme quando, em 2007, os bispos do Brasil, num documento sobre a evangelização da juventude, encararam a juventude como realidade teológica.

Uma forma de dizer o que foram os 10 anos vividos no IPJ é a carta que deixei para meus companheiros de Equipe Executiva do IPJ e funcionários, no dia 12 de maio de 2001, dia de meu aniversário, durante a celebração da Eucaristia. Entre outras coisas, eu dizia que esta carta é uma destas bobagens que cometo poucas vezes na vida. Para mim, completando 64 anos, o assunto mexe muito comigo. Todos os lugares pelos quais passei marcaram-me muito. Até hoje eu morei 11 anos na casa de meus pais, em Santa Cruz do Sul; 8 anos em Salvador do Sul (seminário menor); 3 anos em Pareci Novo (noviciado e juniorado); 12 anos em São Leopoldo (filosofia, letras, teologia, paróquia e Universidade); 15 anos em Porto Alegre (Anchieta e Instituto de Pastoral de Juventude); 5 anos no Rio de Janeiro (mestrado e doutorado em Literatura Brasileira); 3 anos em Brasília (assessor do Setor Juventude, da CNBB); 7 anos em Recife (Universidade Católica de Pernambuco). O lugar onde mais tempo trabalhei, diretamente em Pastoral da Juventude, foi no Instituto de Pastoral de Juventude, de Porto Alegre.

Dizia que só eu sabia o que significava, na minha vida, o Instituto de Pastoral de Juventude, de Porto Alegre. Um dia dei-me conta que estava no Brasil e na América Latina, como um Quixote em busca do coração do jovem sonhando ser protagonista. Acostumei-me a ser chamado de "diferente", de "dinossauro" e outros nomes. Atrevo-me a dizer que não estou na residência atual, na frente da Universidade do Vale do Rio dos Sinos, por um mero acaso. Deus, que vai caminhando com a gente, também quer que a gente 
seja protagonista e sujeito da história. O encaminhamento e a realização do Curso de Pós-Graduação em Juventude, nesta Universidade, foi uma destas veredas que abriu fronteiras novas e foi revelando novas possibilidades. É preciso que ele se torne, contudo, devagarinho, um novo desafio para o mundo da academia. É o jovem entrando, pelas portas dos fundos, com vontade doida de ser levado mais a sério.

Eu também afirmava:

Deixar o ninho não é só deixar o ninho. Quantos relacionamentos vão mudar de casa! Quantas ternuras vão ter que encontrar outras formas de acarinhar! É verdade que a nova residência não fica longe, mas ela é outra. Muito outra... No silêncio dos olhares, meus e de outros/as, percebo que preciso aprender a tornar a perda em ganho. Não é simples aceitar que a encarnação da utopia não é mais jardim, não é mais corredores, não é mais chegada da gurizada, não é mais chimarrão tornando-se sacramento juvenil, não é mais grito de gente que busca sentido. Estou quase a jurar que não deixarei de visitar sempre esta encarnação. Ela se chama equipe, biblioteca, pessoas lindas e buscadeiras, banco de dados, assessorias, funcionárias/ os, brigas, cozinha, violão, cursos sonhados e armados, cervejas que são mais do que cervejas, pizzas que não são somente pizzas. Ovo que é mais do que ovo; mamão que é mais do que mamão; nata que é mais do que nata.

\subsection{Estudar juventude, preocupando-se com ela}

\footnotetext{
${ }^{3}$ Realizaram-se mais duas outras edições do Curso de Pós-Graduação sobre juventude, na UNISINOS. Na $3^{\text {a }}$ edição, com 19 alunos provindos de Roraima, do Amazonas, do Pará (Ilha de Marajó), da Rondônia, de Tocantins, de Goiás, da Bahia, do Mato Grosso do Sul, de Minas Gerais, de São Paulo, de Santa Catarina e do Rio Grande do Sul. Tinham vindo para aperfeiçoar-se no trabalho que já estavam fazendo com a juventude: professores públicos, responsáveis de ONGs, assessores da Pastoral da Juventude, agentes de Centros e Institutos de Juventude, sendo leigos/as, Salesianos/as, Maristas, Lassalistas, Agostinianas, Irmãs da Divina Providência, Irmãs Escolares de Nossa Senhora, Pavonianos, Estigmatinos, Cônegos Lateranenses e Jesuítas. Além de não ser barato, o curso exigia dos alunos três deslocamentos onerosos, quase correspondentes ao preço do curso como tal. As avaliações do curso estão para demonstrar a satisfação afirmada com relação a ele. Foi esta uma das razões para que, mais adiante, o curso fosse transferido para Goiânia, onde, em 2006, começava uma nova turma com 48 alunos.
}

Quando fui transferido para a residência da UNISINOS (São Leopoldo), em 2001, vinha, pois, com vontade de prosseguir na implantação da reflexão sobre a juventude na Academia. Por isso, após um convênio assinado entre o IPJ e a UNISINOS, em 1998, comecei a trabalhar no Centro de Documentação e Pesquisa (CEDOPE) e, em 1999, com grande alegria, começava o Curso de Pós-Graduação: Especialização em Juventude, coordenado pela Prof ${ }^{a}$ Valburga Streck e por mim, a pedido do Diretor do Centro de Ciências Humanas, Pe. José Ivo Follmann.

Dentro da Universidade, junto com a Prof ${ }^{a}$ Valburga Streck, éramos a Coordenação desse Curso de Pós-Graduação sobre juventude, sediado naquilo que seria reconhecido como "Observatório Juvenil do Vale", um lugar de pensar, academicamente, a juventude. A primeira pesquisa que foi publicada referia-se ao imaginário religioso do estudante da UNISINOS ${ }^{3}$.

\subsubsection{Olhando no retrovisor...}

Mesmo sem ter mais interferência no andamento do IPJ, vendo os problemas que lá passavam (econômicos, de 
${ }^{4}$ Em 2010 deu-se não a "refundação", mas a declaração do fim do IPJ por razões que não se explicam nem justificam. A carta do Conselho Superior, de 18 de junho de 2010, é uma espécie de declaração de falência de algumas Congregações, sentindo-se incapazes (ou não querendo) de levar em frente este serviço dedicado à evangelização da juventude.
${ }^{5}$ Em fevereiro de 2006 a ameaça sobre o IPJ ficou real... Depois de o Provincial dos jesuítas, Pe. Geraldo Kolling, ter-se reunido com a Equipe Executiva, em agosto de 2006, ouvindo os planos que ela tinha, simplesmente concluiu a conversa dizendo que o IPJ seria ocupado pela UNISINOS para implantar aí uma Escola de Design. relacionamento e de concepção), em inícios de 2004 decidi ir a campo para resgatar a memória do IPJ, lançando ou reforçando a necessidade de uma possível "refundação"4. Além do mais, o Curso de Pós-Graduação em Juventude, que começara em 1999, realizava-se em parceria com o IPJ. É uma longa reflexão que não deixa de recordar que o IPJ nasceu num tempo em que a Igreja da América Latina optava pela juventude. $\mathrm{O}$ ar que se respirava na "pastoral", por isso, era de abertura e de compromisso com o social. Não satisfaziam respostas desconectadas da vivência da opção pelos pobres. A Igreja e fortes segmentos da sociedade viviam esse ambiente. $\mathrm{E}$ a análise tomava várias direções.

Destacando os trunfos da caminhada acentuava seis: a intercongregacionalidade como algo raro de encontrar na Igreja; a proposta pedagógica, teológica e pastoral clara e corajosa com relação ao trabalho de evangelização da juventude; a vida da Equipe com os "liberados" pelas Congregações, a "liberação" de pessoas com vocação para este trabalho; as funções bem definidas, havendo "trabalhos especializados" para todos, surgindo uma bonita complementaridade; o fato de ser referência no trabalho com a juventude em nível de Brasil e de América Latina; a pedagogia que orientou o todo do IPJ.

Procurei apontar, igualmente, os passos da desconstrução do IPJ: a desconstrução da vida comunitária da Equipe Executiva; a admissão de novos participantes do caráter inter-congregacional da obra, sem compromissos definidos; a "nomeação" de administradores sem visão pastoral; o ingresso, na Equipe Executiva, de pessoas sem opção pela juventude ou sem condições de viver essa opção; o progressivo descompasso dos/as Provinciais com a finalidade do IPJ; a não realização dos momentos de celebração e de revisão de vida e de prática por parte da Equipe; a desconsideração progressiva do Plano Anual de Atividades; o desrespeito que foi crescendo com relação ao espírito de equipe, da Equipe Executiva; o não aprofundamento e a má condução da questão dos leigos na Equipe.

Apontavam-se, ainda, outras causas da situação: o IPJ não ser mais "coordenado" pela Equipe Executiva, mas por pessoas que estão "fora" da obra; o IPJ deixar de ser dono de sua fundação; o discurso de que o IPJ deveria ser sementeira de vocações religiosas; a falta de carinho com o IPJ, por parte das Congregações, afirmando-se que várias conquistas deveriam ser implementadas: o preparo pedagógico dos que trabalham no IPJ, o amor fundamentado à causa juvenil, o profetismo, o espírito orgânico (inserção na Pastoral de Conjunto) e o cultivo da utopia juvenil ${ }^{5}$.

Prossegui trabalhando na Universidade, no IHU (Instituto Humanitas Unisinos), principalmente na pesquisa sobre juventude. Uma dessas pesquisas foi concluída no final de 2006 com bastante repercussão: Discursos à beira do Sinos - a emergência de novos valores na juventude - o caso de São Leopoldo. Antes, já saíra outra publicação com o título Às margens juvenis do Vale. Foi enorme 
a minha vibração quando vi, no Auditório Central da UNISINOS, mais de 300 jovens das periferias de São Leopoldo dispostos a verem e ouvirem o resultado da pesquisa feita sobre eles. Junto com os jovens, estava o Reitor da Universidade da Universidade, o Prefeito da cidade, vereadores, agentes de movimentos sociais e outros.

\subsection{Revisão de vida}

\subsubsection{Visão septuagenária}

Em 2007, uma pergunta que fazia a mim mesmo nos dias que ia vivendo foi: o que faz o Hilário, neste momento? Como está o Hilário? Vou tentar dizer o que pensei e o que sentia. Por isso, quando completava 50 anos de vida religiosa e 70 anos de vida, escrevi, quase sem querer, uma crônica. Era 12 de maio de 2007. Os meus amigos e amigas fizeram-me ver que ela diz muito de como estou e como me sinto. O que dizia eu naquela crônica? Pus como título "70 supõe 50...", e ela começava dizendo: Dizem que ao chegar aos 70 começa a nascer a vontade de recordar. Não quero fugir dessa divina tendência. Fiquei pensando no que faria neste dia em que completo 70 anos de vida e festejo, com meus amigos e amigas, os 50 anos de vida religiosa. Decidi: vou recordar! De forma abreviada, mas com algumas coisas que consigo sentir e agradecer nesta data. Meu dia de aniversário sempre tem uma forte concorrência: o dia das mães e é por isso que vou dedicar o que escrevo a esta mãe (nossa e minha). Nascer, em todos os sentidos, tem tudo a ver com a mãe. Que ela, lá do céu, abençoe a mim e a todos e todas, em todos os nossos sonhos e desajeitos.

\subsubsection{Três vocações}

Falei de minhas três vocações: Nas minhas confidências sempre digo que tive três vocações: a de ser padre, a de ser jesuíta e a de ser um padre dedicado à juventude. Onde me firmei mais foi na terceira, e não estou arrependido. A imagem pretensiosa que se levanta em mim, nos últimos meses, é a de Dom Quixote. Aliás, é a obra que estudei na perspectiva juvenil. Toda pessoa precisa ter uma "causa", assim como o magro Quixote. Como Quixote, tive a ventura de voltar, nestes dias, à cidade do Rio de Janeiro onde os jovens plantaram, em mim, esta bandeira. Encontrei-me, para celebrar, com uns quantos deles - agora todos casados, lutando na vida e não deixando de me recontar os anos que entre eles vivi. São dessas coisas de matar...

Dizia: Fico pensando na necessidade maluca que a "gurizada" tem de referenciais. Todos nós, aliás, precisamos de modelos. Não é por nada que o Nazareno disse que Ele é o Caminho, a Verdade e a Vida. Lendo certos recados escritos por jovens e adolescentes, arrepio-me pensando 
como é importante encontrar gente que esteja de bem com a vida, mesmo no meio dos atropelos. Estou aprendendo que, para estar do lado dos jovens, não podemos trilhar o caminho da vaca, isto é, precisamos ter aspectos de "desviantes". A gente, contudo, não é "desviante" porque decide sê-lo, mas porque a gente é, simplesmente, sem encontrar muitas fórmulas. Um dos aspectos do "desviante" é que ele sabe rir das coisas. Por isso que o jovem é o sacramento da alegria.

\subsubsection{Utopia}

Nos 50 e 70 anos que vivi dei-me conta de que larguei muita coisa. Larguei a família (que adoro); larguei casar (que adoro); larguei ter coisas (que adoro); larguei a literatura (que adoro); larguei a UNISINOS (que não adoro tanto); larguei o IPJ (que adoro e sofro com o que fizeram com ele. Um pecado!); enfim, larguei muita coisa para abraçar outro aspecto da causa. A causa do Reino traduziu-se, não sei como nem por que, na causa pela juventude. Dizer isso até parece presunção, mas é a utopia que não estou querendo largar. Na juventude, de repente, está tudo. Outra coisa que vou verificando é que minha vida mudou em agosto de 1975, quando comecei a penetrar numa nova olhada para o mundo, a fé e tudo mais, através daquilo que se chama "Teologia da Libertação". $E ́$ um estilo novo de vida onde tudo é o mesmo, mas não é o mesmo. Aprendi que a felicidade, a libertação, o conflito são a mesma coisa, mas diferentes. Poderia dizer que aprendi a ter uma ideia fixa. Ter uma ideia fixa é ter um projeto de vida que seja pessoal, baseado no Evangelho, dando lugar preferencial aos empobrecidos. Tudo se veste de algumas mesmas cores, também a pedagogia, também a espiritualidade, também a Teologia. Tudo. E nisso o Quixote se revela como um eterno cavaleiro andante dando a vida por sua Dulcinéia... Aprendi que precisamos ter uma proposta, no seu todo e na sua tradução pedagógica. Por isso que me assanho, por exemplo, quando se fala de "opções pedagógicas" na evangelização da juventude.

Olhando-me no que consigo ser destacaria três aspectos, como bom jesuíta: sem ser historiador sou um amante da memória histórica, também no trabalho com os jovens; sem ser teólogo, sou um batalhador neófito do divino que se encarna no jovem. O grande discurso, como Igreja, é sobre o jovem como realidade teológica; sem ser um pedagogo, quem deseja trabalhar com jovens deve ser um Neotéfilo, um amante da juventude. Por isso que me agrada trabalhar com assessores e animadores de jovens. Enfim, nada mais do que agradecer. Sempre me lembro dos meus 18 anos lendo "Diário de um pároco de aldeia", de Georges Bernanos. Aquele final do romance dizendo que "na vida tudo é graça" nunca me abandonou. Nem nos meus 70 anos. Por isso, nada mais divino do que dizer que "tudo é graça". 
Estou convicto que há diferentes formas de estudar o fenômeno juvenil. Uma coisa é ler os discursos que os jovens fazem através de pesquisas, entrevistas, visitas etc. e outra coisa é descobrir o que a sociedade diz da juventude ou faz os jovens dizerem. Neste campo entra minha leitura das obras literárias no viés juvenil. É o que vou fazendo aos poucos. Vendo o que faço, considero-me um intelectual orgânico no campo da evangelização da juventude. É o que fiz, também, no documento que os bispos lançaram em maio deste ano (2007). É nesta perspectiva que coloco minhas correrias mundo afora, trabalhando com maristas, trabalhando no Curso de Assessores, no Curso de Animadores, nas assessorias regionais e dioceses, nas assessorias a religiosos e religiosas, nos cursos que dou para jovens de dioceses e paróquias, nas palestras que dou aqui e acolá etc.

Falando de vida, nunca se chega ao fim. Aí estão as poucas coisas que fui como educador. Entrei em poucas salas de aula na UNISINOS, no Colégio Anchieta, na UNICAP, mas foi bom, embora minhas "salas", nestes 40 anos envolvidos com a juventude (eu dizia que nasci para a juventude com 37 anos), tenham sido outras. Falei do Curso de Assessores de Jovens, das assessorias em muitos lugares, das pós-graduações relacionadas com a formação sobre e para a juventude em Bogotá (ITEPAL), em São Paulo (Pio XI), em Florianópolis (ITESC), em Porto Alegre (pós-graduação em juventude), em Goiânia (CAJU), em vários países da América Latina, muitas vezes falando de História dos Jovens e da Pastoral da Juventude. Talvez tivesse que falar mais do Instituto de Pastoral da Juventude porque ele pode ser considerado o símbolo de minha opção pela juventude. Pelo que escrevi dá para adivinhar os diferentes espaços em que naveguei, nem falando dos artigos que publiquei nem das milhares de vibrações que tive em eventos, encontros de pessoas, caminhadas de amadurecimento e comprometimento.

Sou um Doutor em Letras que resolveu se doutorar em Juventude tornando-se o que se falava, em outros tempos, de "intelectual orgânico". Se tivesse que apontar três aspectos que vivi e que me orgulham falaria do jovem na Bíblia, do Divino no Jovem e das produções sobre a história da juventude. O grande campo de sonhos foi o IPJ de Porto Alegre e, dentro dele, a formação de assessores, a construção de uma biblioteca sobre juventude e o estudo acadêmico do que não deixo de dizer: do "sacramento da novidade", o jovem. Enquanto escrevo isso tive que descobrir que quase $25 \%$ dos adolescentes/jovens de minha região são infelizes e isso me dá vontade de viver muito mais. 


\section{A VIDA}

Alguém poderia explicar

Se os carinhos abafam?

- Claro que sim! Claro que não!

- Sentir-se amado é sempre uma graça.

É o que senti ontem, no dia em que nasci

Há 78 anos.

Alguém poderia explicar

Se o amor se agradece?

- Claro que sim! Claro que não!

É o que tenho vontade de fazer

Mas sempre somos pequenos diante de gestos de carinho.

Alguém poderia explicar

Se o ser amado cansa?

- Claro que sim! Claro que não!

É por isso que custou adormecer ontem...

Alguém poderia dizer

Por que a gente escreve uma linha, uma palavra, uma página Querendo dizer muito mais?

- Claro que sim! Claro que não!

Por isso que não consegui mais chorar...

Alguém poderia explicar

Se as lágrimas têm idade?

- Claro que sim! Claro que sim!

GRACIAS... 